\title{
Production and Supply Chain Operation Planning "Minuman Nanas" Innovation of Subang Honey Pineapple Beverage
}

\author{
Saputra Tri Wardana ${ }^{1}$, Rhian Indradewa ${ }^{2}$, Tantri Yanuar Rahmat Syah', \\ Ketut Sunaryanto 4 \\ ${ }^{1,2,3,4}$ Department Management, Faculty Economic and Business, Esa Unggul University, Jakarta - Indonesia \\ Corresponding Author: Saputra Tri Wardana
}

\begin{abstract}
Background - PT. Limatra runs the business of manufacturing and selling pineapple beverage products with various variants. PT Limatra provides packaged pineapple fruit juice products derived from $100 \%$ pineapple juice without the addition of preservatives. With $100 \%$ pineapple juice, of course it has a high vitamin $\mathrm{C}$ content as well. With the use of UHT (Ultra High Temperature) technology in the maklon industry and the use of aseptic paperpack packaging, it can produce good quality fruit juice products, maintain the freshness of the juice and have a relatively long product durability. PT Limatra provides solutions, namely: (1) Providing pineapple juice products with different flavors (mixed apple, mango and orange); (2) Providing pineapple juice products using aseptic paperpack packaging technology; (3) Using UHT technology to maintain the freshness and durability of the product; (4) Products that provide $100 \%$ pure fruit juice without additional formulas. To produce superior products requires an optimal operational plan.

The method used is descriptive method.

Results- From the results of the analysis and design of the operational plan, the Stages of Business/Business Establishment, Operational Goals and Targets, Operational Design, Operational Delivery, and Operational Cost Projections are generated.
\end{abstract}

Keywords: Minuman Nanas, Subang Honey Pineapple Beverage, Production and Supply Chain Operation

\section{INTRODUCTION}

Awareness of people's healthy lifestyle and thinking back to nature makes people in Indonesia choose healthy and fibrous foods such as vegetables and fruits. Drinks made from fruit are natural healthy drinks that are naturally natural in Indonesia. Unfortunately, the types of healthy drinks made from fruits with no artificial sweeteners and artificial preservatives are still very limited in variants. Currently, Indonesia has the largest number of businesses in the culinary field. In addition, the public's desire for entrepreneurship through MSMEs, especially in the food and beverage sector is also very large. Based on survey data, $73 \%$ of Indonesians are very concerned about health. In addition, people's desire to become entrepreneurs is also very high, this can be seen from the increase in SMEs by $2.8 \%$ every year. (Supriyanto, 2021) This is a potential opportunity for people to improve their lives through advanced businesses in the beverage sector. Pineapple itself in West Java is a very productive commodity. However, a lot of fruit is produced at harvest but only sold in the form of raw fruit without further processing. Advanced processing in marketing science will provide more value from the marketing aspect which will increase the income of Pineapple farmers and their distributors. Production which is one of the economic behaviors to produce quality products with a 
supply chain that presents quality products to consumers and is ready to be enjoyed is something most important in the performance of SMEs.

Supply Chain - The company's success depends on the way the company carries out a quality, timely and much cheaper production process. Supporting components in the supply chain must work well, structured and synergistically. The risks that occur in the supply chain include: quality, delivery delays, increased costs, long lead times and limited capacity, so the approach to the processquality, delivery delays, increased costs, length of lead time and limited capacity, so that the approach to the risk identification process is prioritized on the quality and quantity of supply, time and cost.

The establishment of PT Limatra is in accordance with RI Law No. 40/2007, online by appointing a notary through the Ministry of Law and Human Rights Administration system. For the submission of the name of the PT based on the Law on PT and Permen Number 43/2011 concerning Procedures for Submitting and Using the Name of PT. Making a Certificate of Company Domicile (SKDP) submitted by the local sub-district office.

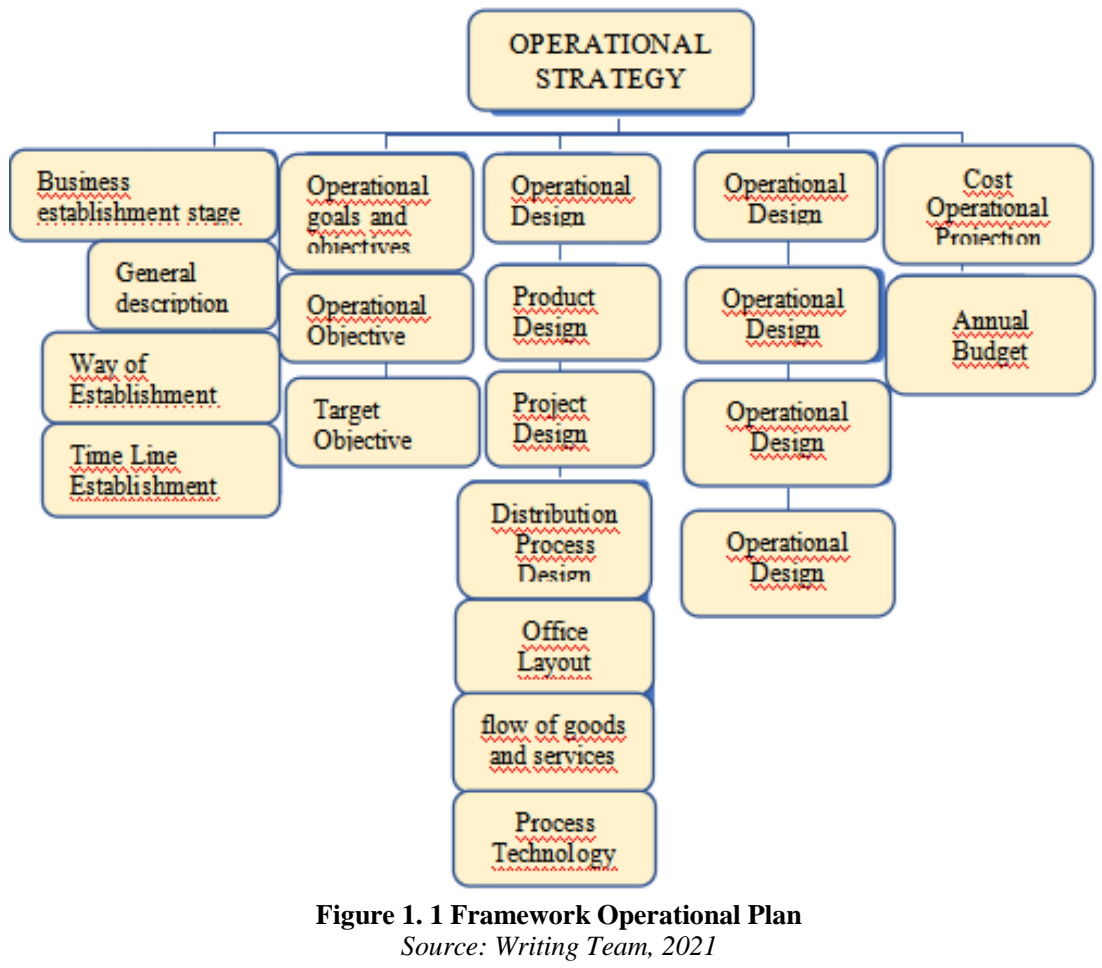

The process of the Deed of Establishment of a business entity is carried out by making a Deed of Establishment at the Notary's office. To avoid reading your company data in the OSS system, make sure that the business fields listed in your company's Deed of Establishment are updated and follow the 2017 Indonesian Business Classification Standards (KBLI) (Taryana, 2021)

\section{DEVICES AND METHODS}

\subsection{Stages of Establishing a Business/Business}

PT Limatra which complies with the Law of the Republic of Indonesia No. 40 of 2007 which contains about how to regulate a Limited Liability Company (PT). Management of the establishment of PT LIMATRA is carried out online by appointing a notary through the Legal Entity Administration system of the Ministry of Law and Human Rights (Kemenkumham) by fulfilling several requirements including 
a photocopy of the National Identity Card (KTP) and photocopy of Identity Card (KTP) and Family Card (KK) of the founder. The next process is to submit the name of the PT based on the Company Law and Ministerial Regulation Number 43 of 2011 concerning Procedures for Submitting and Using the Name of a Limited Liability Company, this process aims to check the name of the PT so that it is not the same as or similar to the name of an existing PT. The deed of establishment is made by an authorized notary to obtain approval from the Minister of Law and Human Rights. Making a Certificate of Company Domicile (SKDP) which submitted to the local kelurahan office at the address Jl Raya Cagak, Subang Regency. The choice of office in Subang is adjusted to access product distribution in Subang City.

The founder of PT Limatra, of course, already has the criteria for establishing a company, namely at least 2 people with the aim of becoming a company that provides natural pineapple fruit drink products and without preservatives. The capital of PT Limatra is IDR 6,000,000,000 (Six Billion Rupiah) originating from dari $70 \%$ dan $30 \%$.

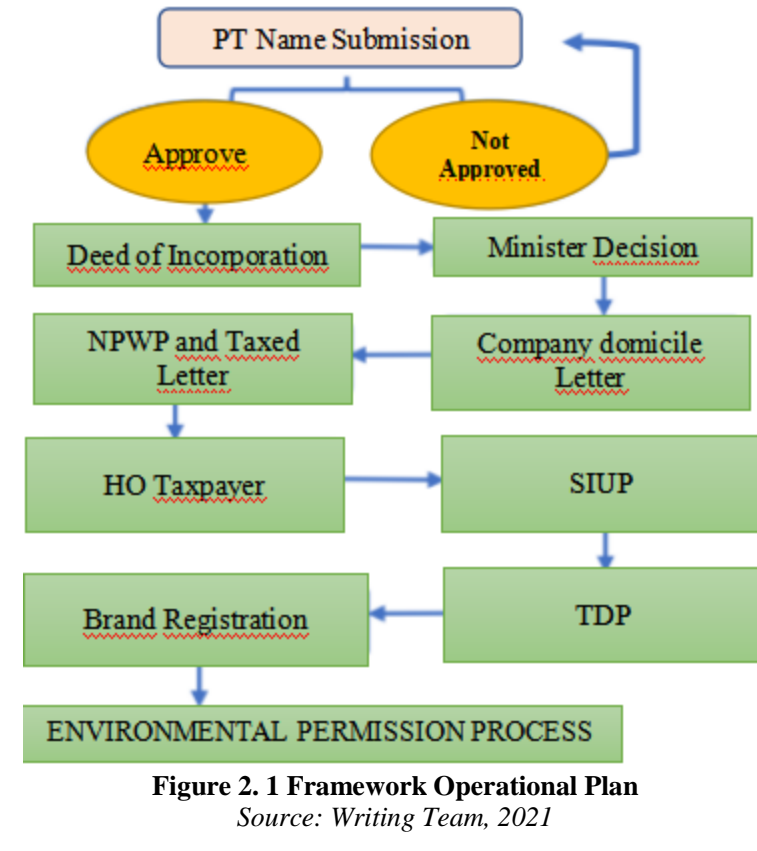

Furthermore, the company logo of PT Limatra. Our company logo uses a pineapple leaf accent which is distinctively cut and facing upwards, it is hoped that the new company will grow and dominate the market. For the product logo, it looks like flowing water, representing this product, prioritizing fresh beverage products.

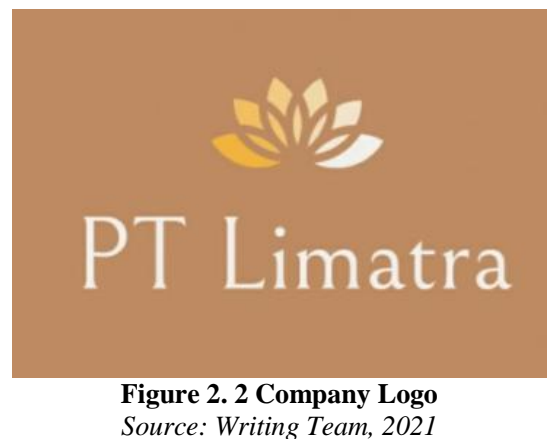

Establishment Timeline; Before PT Limatra did the production of national drinks, we prepared all the needs for the establishment of the company. There are several things that we need to prepare in advance, such as a survey for the tolling factory and the company's operational office.

\begin{tabular}{|c|c|c|c|c|c|c|c|c|c|c|c|c|c|c|}
\hline \multirow{2}{*}{ No } & \multirow{2}{*}{ Timeline } & \multicolumn{13}{|c|}{ Months } \\
\hline & & 1 & 2 & 3 & 4 & & & 6 & 7 & 8 & 9 & 10 & 11 & 12 \\
\hline 1 & Business License & $\mathbf{X}$ & $\mathbf{X}$ & & & & & & & & & & & \\
\hline 2 & $\begin{array}{l}\text { Maklon Survey and } \\
\text { Operational Office }\end{array}$ & $\mathbf{x}$ & & & & & & & & & & & & \\
\hline 3 & Building Renovation & $\mathbf{X}$ & $\mathbf{x}$ & $\mathbf{x}$ & & & & & & & & & & \\
\hline 4 & $\begin{array}{ll}\text { Operational } & \text { Office } \\
\text { Layout Settings } & \end{array}$ & & & & $\mathbf{X}$ & & & & & & & & & \\
\hline 5 & Office Asset Purchase & & & & $\mathrm{X}$ & & & & & & & & & \\
\hline 6 & Employee Recruitment & & & & & & & $\mathbf{X}$ & & & & & & \\
\hline 7 & $\begin{array}{l}\text { Digital Marketing } \\
\text { Registration and Offline } \\
\text { Store Survey }\end{array}$ & & & & $\mathrm{x}$ & & & $\mathbf{x}$ & $\mathbf{x}$ & & & & & \\
\hline 8 & Product marketing & & & & & & & & & $\mathbf{X}$ & & & & \\
\hline
\end{tabular}

\subsection{Operational Goals and Objectives}

Operational Objectives; PT Limatra will develop operational objectives through several stages, as shown in the table below.

\begin{tabular}{|c|c|}
\hline Kategori & Tujuan Operasional \\
\hline $\begin{array}{l}\text { Short-term } \\
\text { (1-3 Years) }\end{array}$ & $\begin{array}{l}\text { 1. Provide a means of delivery of finish good from tolling } \\
\text { to the sales area } \\
\text { 2. Provide coller box facilities to freelancers } \\
\text { 3. Provide product licensing and business license } \\
\text { management } \\
\text { 1. Define } 2 \text { macros }\end{array}$ \\
\hline $\begin{array}{l}\text { Medium-term } \\
\text { (3-5 Years) }\end{array}$ & $\begin{array}{l}\text { 1. Developing flavor variants } \\
\text { 2. Addition of a finish good delivery facility from tolling } \\
\text { machines to point of sale throughout West Java }\end{array}$ \\
\hline $\begin{array}{l}\text { Long-term } \\
\text { More than } 5 \text { Years }\end{array}$ & $\begin{array}{l}\text { 1. 1.Products with premium packaging (Family Pack 1L) } \\
\text { 2. 2. Opening KCP (Sub-Branch Office) PT Limatra on } \\
\text { the border of West Java-Central Java and Central } \\
\text { Java-East Java } \\
\text { 3. Added } 3 \text { macros in the expansion area }\end{array}$ \\
\hline
\end{tabular}


Saputra Tri Wardana et.al. Production and supply chain operation planning "minuman nanas" innovation of subang honey pineapple beverage.

\section{Operational Goals:}

\begin{tabular}{|c|c|}
\hline Kategori & Sasaran Operasional \\
\hline $\begin{array}{l}\text { Short-term } \\
(1-3 \text { Years })\end{array}$ & $\begin{array}{l}\text { 1. 1. The distribution channel from aklon to the sales area } \\
\text { is going well } \\
\text { 2. } 2 \text { Keeping products cold so that consumers can enjoy } \\
\text { them } \\
\text { 3. } 3 \text {. Have a PT Limatra office in the city of Subang } \\
\text { 4. 4. The quality of the product and company is met } \\
\text { 5. Product is working well }\end{array}$ \\
\hline $\begin{array}{l}\text { Medium-term } \\
(3-5 \text { Years })\end{array}$ & $\begin{array}{l}\text { 1. 1.Do research and developm ent to develop } 5 \text { flavors } \\
\text { 2. Make QC (Quality Control) visits to tolls more often }\end{array}$ \\
\hline $\begin{array}{l}\text { Long-term } \\
\text { More than } 5 \text { Years }\end{array}$ & $\begin{array}{l}\text { 1. Developing Family Pack packaging products } \\
\text { 2. Our products can be received throughout the island of } \\
\text { Java Products throughout Java are going well }\end{array}$ \\
\hline
\end{tabular}

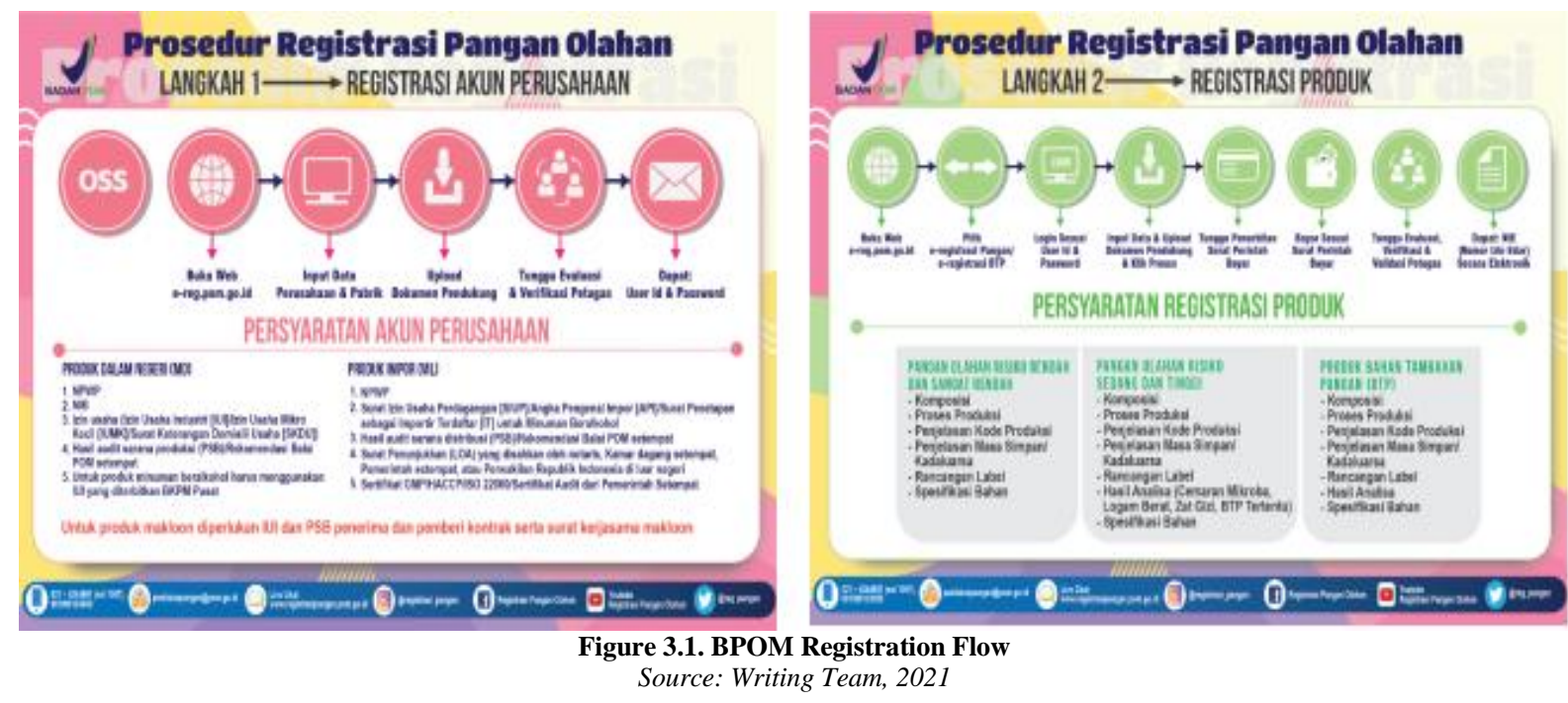

\section{DISCUSSION}

\subsection{Operation Design}

National Drinks Product Design

Before we carry out the product processing, of course we do product samples and must be tested for product durability and taste quality. After our sample is made and is suitable for production, we carry out a BPOM permit in accordance with the provisions of BPOM concerning Processed Food Registration 26/2018 and BPOM Regulation 27/2017
Industries where tombs use paperpack packaging (the material consists of cardboard with plastic and aluminum layers) can produce superior product quality fruit juices that are good, maintain the freshness of the juice and have a relatively long product durability. Aseptic packaging is a method of packaging that is carried out under sterile and bacteria-free conditions and packaging. Because it uses aseptic conditions, the Nasnas packaging is safe. With 6 layers, it will protect from outside air humidity, oxygen and light which can reduce nutritional value. PT Limatra is trying to develop old products by adding flavor variants and developing premium $1 \mathrm{~L}$ Familypack products as follows:
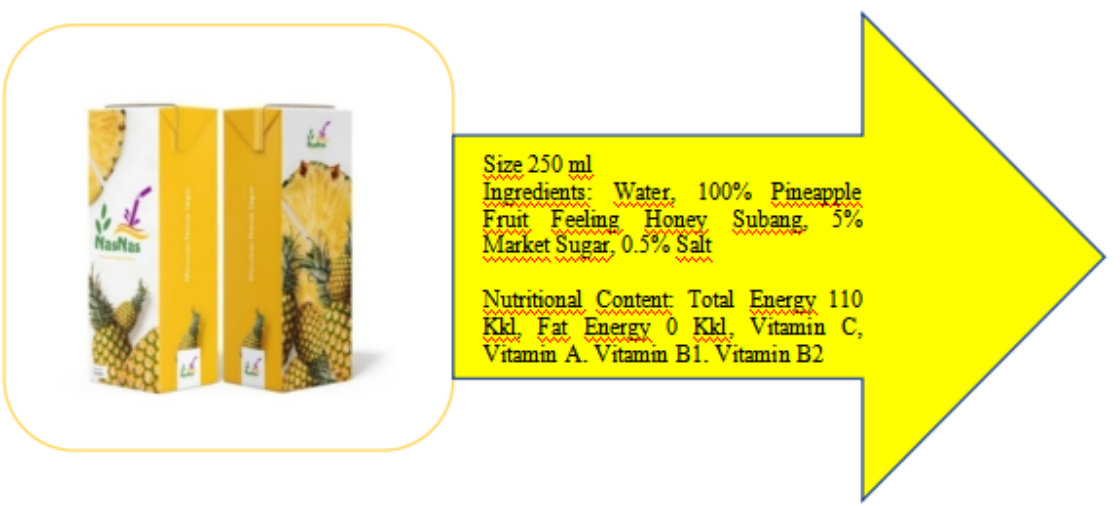

Figure 3.2 Aseptic paperpack packaging and familypack packaging Source: Writing Team, 2021 


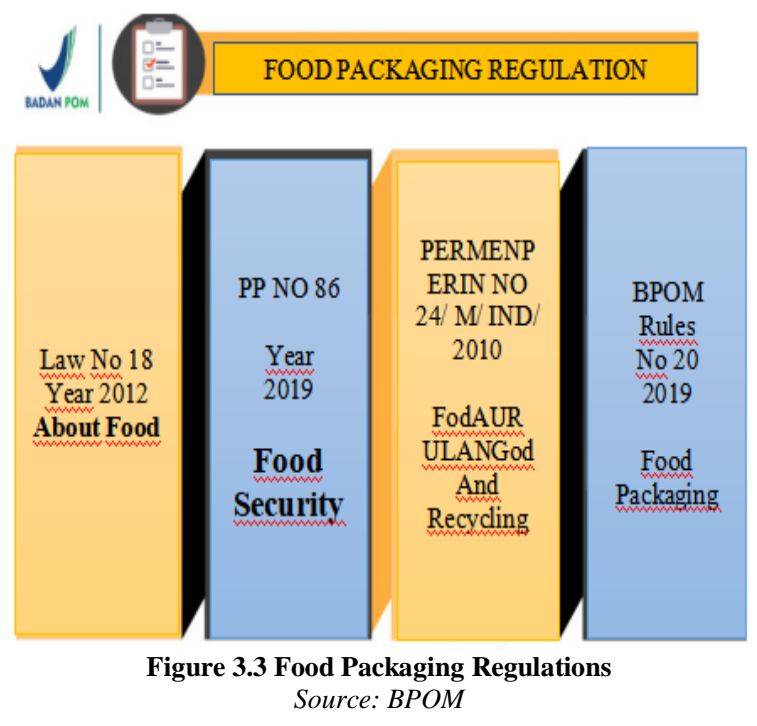

3.3.1. Process Design; At PT Limatra in meeting consumer needs related to national beverage products. This is the main goal that become mind-set (Prabangkara, 2021) .PT Limatra carried out the stages with the process design carried out as follows:

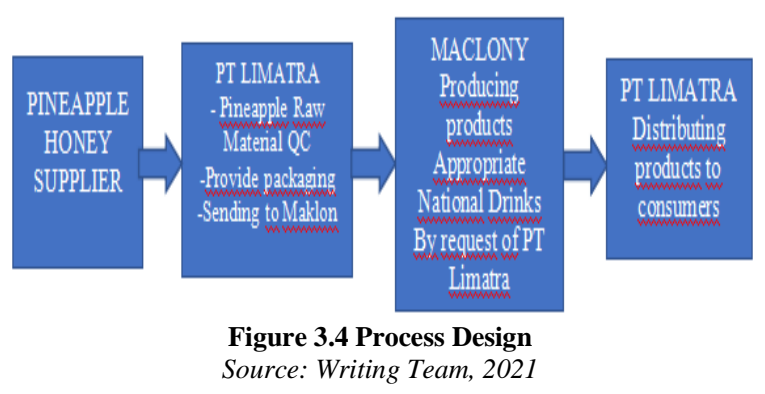

3.3.2.Distribution Process Design; The distribution channel is an organizational structure within PT Limatra which consists of consumers in Subang City, and visitors to tourist attractions. Distribution or distribution of products in our business plan according to QSPM point 4.5 Decision Stage begins with market penetration and product development.

3.3.3.Office Layout / Flow of Goods and Services; Layout is one of determining the efficiency and operation process in the long term. PT Limatra carries out product procurement activities at the tolling place, layout and stock storage as follows:

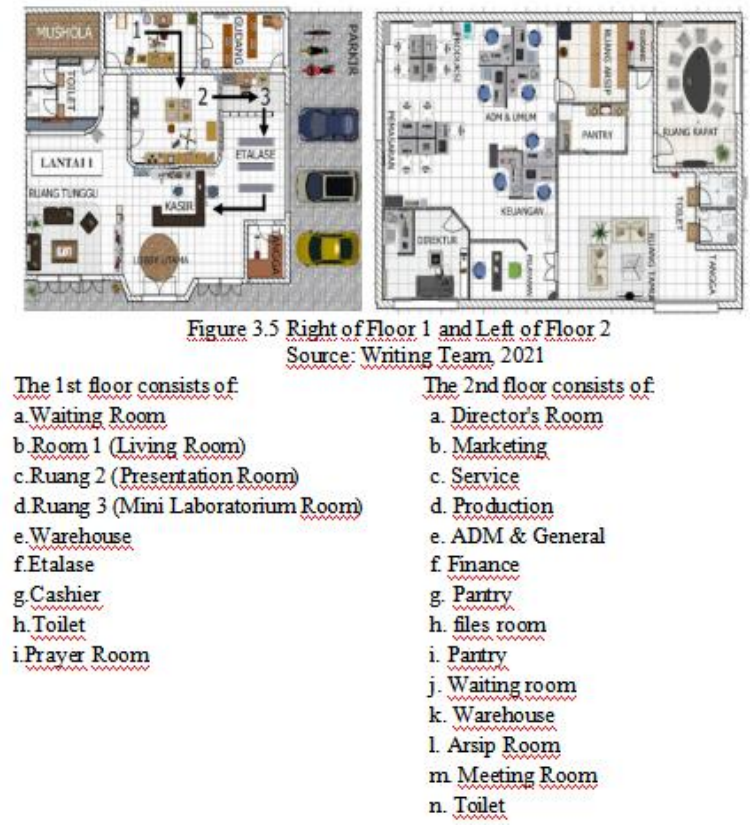

\subsubsection{Flow of Goods/Services}

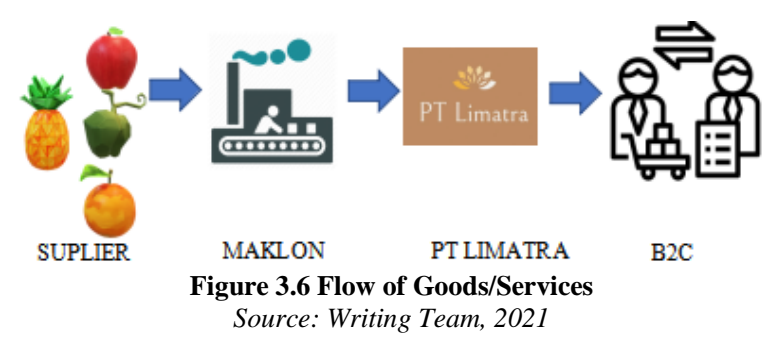

Pineapple raw materials are taken directly from farmers with selected quality. PT Limatra provides pineapple farmer groups Subang honey

- Production of fruit juice by a designated tolling company. Production process see attachment 6.2

- PT Limatra Receive products and store in Subang

- Delivery to B2C customers

\section{Process Technology}

In the cooking process we use UHT (Ultra High Temperature) technology. Ultra High Temperature (UHT) technology is a heating technology with very high temperatures $\left(100^{\circ}-120^{\circ} \mathrm{C}\right)$ for only $2-4$ seconds. This technology aims to kill bad bacteria that can cause disease and decay. With this technology, Buavita juice does not require preservatives and can last a long time. Our production system uses continue 
flow with a production capacity of 1,728 pcs per day. The machine from Maklon for national beverage products uses Eco Struxure technology. As information, this technology will integrate the industrial internet of things with automation technology in all aspects of basic raw material needs. Eco Struxure technology solutions integrate four aspects (smart manufacturing, smart facilities, smart food safety, smart supply chain). These four aspects are expected to improve our industrial business performance and optimize productivity, energy efficiency, as well as maximum transparency and tracking. This technology can also reduce energy costs by $60 \%$ and reduce integration costs by $50 \%$ and reduce operational costs by up to $30 \%$. The company also held discussions to get an overview of the environment of several locations that will be selected to build a waste treatment plant (Ramadhan, 2020)

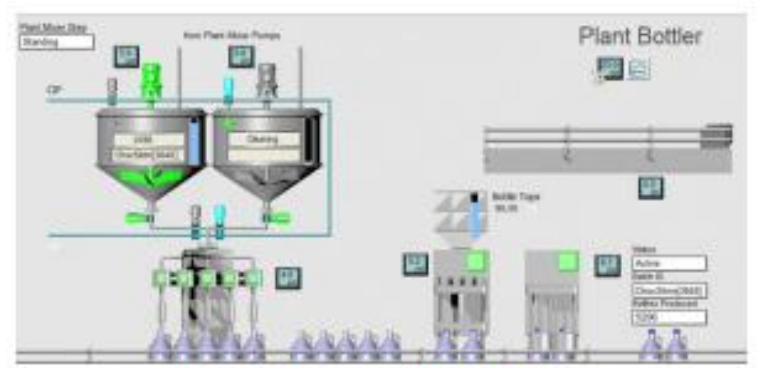

Figure 3.7. Ecostructure Machine

Source: Writing Team, 2021

The cooperation between PT Limatra and Maklon is regulated in a cooperation agreement with a tolling agreement letter with the following points:

a) Willing to follow PT Limatra's request

b) tolling administration fee

c) The duration of the agreement is 3 years (extend the contract is determined on the basis of product results)

d) Agree on toll fees

e) e)Design, product formula made by PT Limatra

f) The industry where the tolling is to be made is not allowed to produce PT Limatra's tolled products for itself

\subsubsection{SIPOC}

SIPOC analysis is used in the preparation of this plan which will include the following, namely suppliers, including everything that provides input or input to the process; input, specify the materials, services, and/or information that will be used by a process to produce output; process, determining the sequence of an existing activity, usually done by adding input values to produce outputs that will be provided to customers; output, namely the result of the process in the form of products, services, and/or information of value for customers; and customers, including all user outputs originating from the process (Hardono, 2021)

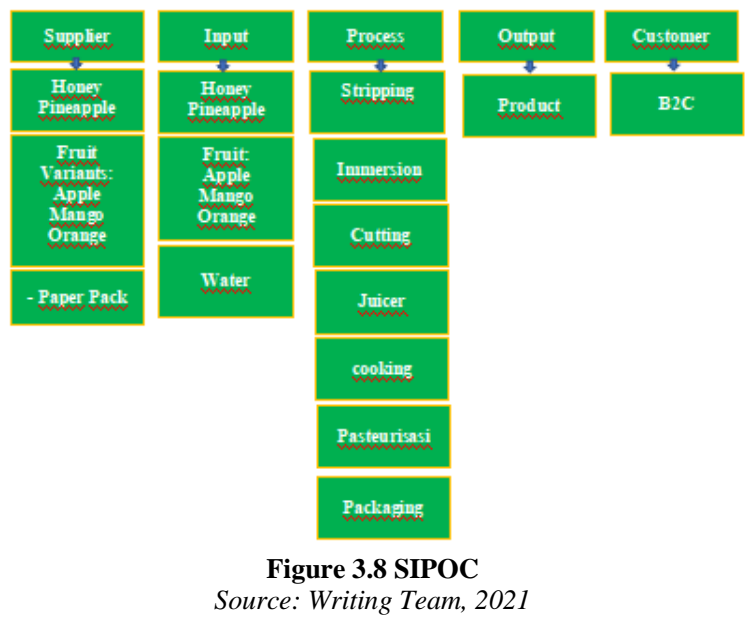

\subsubsection{Supply}

\section{a) Nasnas Beverage Supplier}

Our beverage products, of course, use the basic ingredients of pineapple honey, subang. By relying on subang honey pineapple farmers who are included in the honey pineapple farmer group in Subang.

\section{b) Pineapple Mix Fruit Variants}

In accordance with our company's product innovation by making drink mix pineapple with apples, mangoes and oranges. Of course we need a supply of quality pineapples in order to provide products in accordance with expectations.

\section{c) Paperpack}

For the use of paperpacks in packaging, we use the Aseptic 1000 Ultra 
Edge Paperpack which has the advantage of thicker (polyethylene, aluminum and paper) so that our products can be enjoyed fresh.

\subsubsection{Input}

\section{a) Honey Pineapple}

Chosen honey pineapple by PT Limatra in a half-baked condition. For the selection of half-cooked honey pineapple so that when boiling the pineapple produces a sweet and fresh pineapple essence.

\section{b) Fruit Variants}

The composition that PT Limatra put in is a ripe pineapple fruit drink with a ratio of $60 \%$ pineapple and $40 \%$ mixer fruit (Apple, Mango, Orange). By still highlighting the fresh taste of pineapple and adding a mix of fruit variants, it is hoped that it will add freshness and a different sensation.

\section{liquid}

Our springs use mountain springs, of course, through a fairly tight filter to retain micro-bacteria in the water.

\subsubsection{Process}

The production process starts from sorting pineapples with human labor in order to choose quality pineapples that are in accordance with the company's wishes. After the food sorting process will be carried out peeling the skin of the pineapple and leaves with. After peeling the pineapple, blanching is done (soaking the pineapple to separate the pineapple sap/mucus). Continued for the pulper process (cutting the pineapple into small pieces). In the next process the pineapple will be put in the juicer machine.

\subsubsection{Output}

Our products are $250 \mathrm{ml}$ antiseptic paperpack and 1L Familypack.

\subsubsection{Customer}

B2C consisting of tourists in Subang City and the people of Subang City.

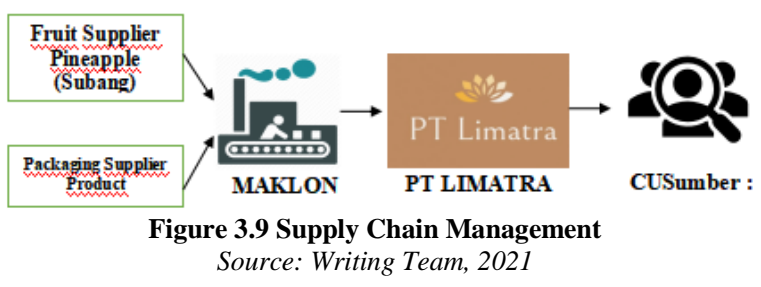

\subsection{Operation Delivery Supply Chain Management}

The supply chain that we focus on is suppliers of pineapples and mixed fruit (apples, mangoes and oranges) which really have to do with the selection of pineapples weighing $3 \mathrm{Kg}$ and a minimum delivery of 5 tons. For packaging, PT Limatra chooses agreed terms to maintain taste quality with aseptic paperpack packaging. Furthermore, the toll will carry out the process as desired.

PT Limatra gives a production deadline to tolls with a monthly production target of 43,200 pcs with a production increase target of $30 \%$ each year. The provisions of the defective product will be returned to the tolling party with the condition that the toll must make the next delivery.

\section{Inventory Control}

Pineapple which is the main raw material for making pineapple juice makes PT Limatra to be able to plan the control of the raw material inventory properly using the FIFO (first in first out) method, a method in which an item that is first entered must also be the first time it is issued or sold. So, the recording of inventory contained in the report will be similar to stock in the warehouse. In addition, so that the production process continues, and also so that the availability of raw materials remains available at any time, both when the pineapple will be produced or at the time of waiting for orders done. The reason we use this method is because we choose raw materials for pineapples that are half ripe so that we send pineapples to tolling machines and the supplies can be fulfilled in the raw material warehouse. In addition, this method also reduces the material loss of pineapple raw material decomposition.

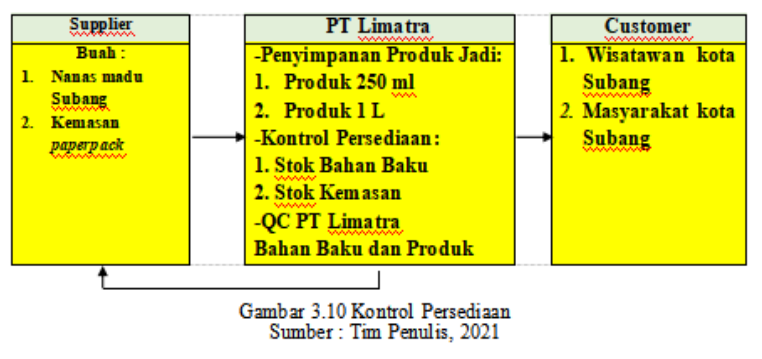


Saputra Tri Wardana et.al. Production and supply chain operation planning "minuman nanas" innovation of subang honey pineapple beverage.

\section{a. Supplier}

1. Educate fruit farmers to provide quality products.

2. Fruit and packaging suppliers always report to PT Limatra the availability of raw materials.

\section{b. PT Limatra}

1. Do the product storage neatly so that the product lasts.

2. Receive reports from suppliers on the availability of processed raw materials and packaging.

3. Checking the condition of raw materials and products.

4. Calculation of stock using the formula (Maximum Usage - Average Usage) x Lead Time.

\section{c. Customer}

\section{d. Enjoy good products in the market.}

\subsection{Quality Management}

In order for product quality to meet consumer expectations, a quality management treatment must be carried out. Quality control is more focused on products, while quality assurance is focused on a series of processes to produce quality products. Quality management in agriculture, especially for national products. For quality management we use ISO 9001:2015 Quality Assurance where we must be responsible for guaranteeing the quality of the product, which is produced. Food management in our company uses ISO 22000:2018 Standard (Safety Management System Food) defines requirements for PT Limatra to demonstrate its ability to ensure that the food is safe for consumption. This standard is established as a guide in the planning, establishment and implementation of a food safety management system, which consists of effective processes and best practices for developing food safety.

\begin{tabular}{|c|c|c|c|}
\hline \multirow{2}{*}{ Asumsi $\mathrm{HPP} / \mathrm{Unit}(\mathrm{Rp})$} & \multicolumn{2}{|c|}{$\begin{array}{l}\text { Kemasan Tetrapack } 250 \\
m l\end{array}$} & \multirow{2}{*}{$\begin{array}{c}\text { Kemasan } \\
\text { Family Pack 1 } \\
\text { L }\end{array}$} \\
\hline & Original & Mix & \\
\hline Prices of Raw Materials Products, & 750 & 1.000 & 1.500 \\
\hline Packaging pes & 980 & 980 & 4.000 \\
\hline Rent Maklon & 1.000 & 1.300 & 1.500 \\
\hline Distribution & 500 & 500 & 500 \\
\hline \multicolumn{4}{|l|}{ Assumption of HPP Increase in Yea 3,5\% } \\
\hline HPP/Unit (Rp) & 3.230 & 3.780 & 7.500 \\
\hline
\end{tabular}

Source: Writing Team 2021

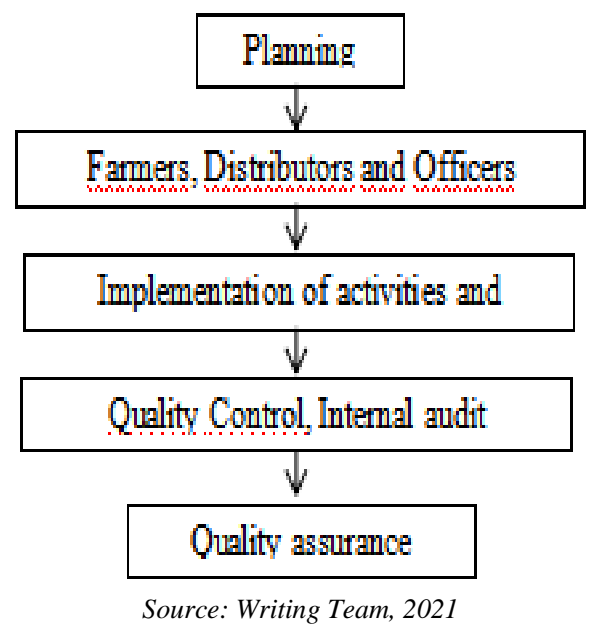

Planning carried out by PT Limatra in terms of planning the fulfillment of fruit raw materials that is adjusted to the sales target. Educate farmers as the main source of our product ingredients so that they produce products according to their wishes. All activities that will be carried out will certainly affect the acceleration of production results. The important role of Quality Control (QC) certainly has a relationship at the time of product finalization. As a support for the smooth fulfillment of raw materials, of course there is a supplier audit. All the products we produce are the result of a product that has a guarantee in terms of taste quality.

\subsection{Operational Cost Projection 3.6.1. Assumption}

Then from a financial perspective, as a new start-up, large funds are needed to start this business and the limited number of resources requires high efficiency to achieve the company's targets (Selfi,, 2021) 
Saputra Tri Wardana et.al. Production and supply chain operation planning "minuman nanas" innovation of subang honey pineapple beverage.

Table 3.1 Assumption HPP

\begin{tabular}{|c|c|c|c|c|c|}
\hline $\begin{array}{c}\text { Perencanaan } \\
\text { HPP } \\
\end{array}$ & Tahun 1 & Tahun 2 & Tahun 3 & Tahun 4 & Tahun 5 \\
\hline \multicolumn{6}{|l|}{ HPP / Unit (Rp) } \\
\hline Mass Product Original & 3,230 & 3,230 & 3,392 & 3,392 & 3,392 \\
\hline Mass Product Mix & 3,780 & 3,780 & 3,969 & 3,969 & 3,969 \\
\hline Family Pack $1 L$ & 7,500 & 7,500 & 7,875 & 7,875 & 7,875 \\
\hline \multicolumn{6}{|l|}{ Unit Terjual } \\
\hline Mass Product Original & 604,800 & 967,680 & $1,548,288$ & $2,477,261$ & $3,963,617$ \\
\hline Mass Product Mix & 151,200 & 241,920 & 387,072 & 619,315 & 990,904 \\
\hline Family Pack $1 L$ & - & - & - & - & 198,181 \\
\hline \multicolumn{6}{|l|}{ HPP (Rp) } \\
\hline HPP Mass Product Original & $1,953,504,000$ & $3,125,606,400$ & $5,251,018,752$ & $8,401,630,003$ & $13,442,608,005$ \\
\hline HPP Mass Product Mix & $571,536,000$ & $914,457,600$ & $1,536,288,768$ & $2,458,062,029$ & $3,932,899,246$ \\
\hline Family Pack $1 L$ & - & - & - & - & $1,560,674,304$ \\
\hline Total HPP (Rp) & $2,525,040,000$ & $4,040,064,000$ & $6,787,307,520$ & $10,859,692,032$ & $18,936,181,555$ \\
\hline Gross Profit (Rp) & $2,842,560,000$ & $4,548,096,000$ & $7,640,801,280$ & $12,225,282,048$ & $20,477,037,773$ \\
\hline
\end{tabular}

Table.3.2.Assumption.HPP/Unit

\begin{tabular}{|l|c|c|c|}
\hline \multirow{2}{*}{\multicolumn{2}{|c|}{ Rincian Sewa Malklon }} & \multicolumn{3}{|c|}{ HPP/Onit } \\
\cline { 2 - 4 } & 3230 & 3780 & 7500 \\
\cline { 2 - 4 } & Original & Mix & Famiby Pack \\
\hline Manpower & $\mathbf{5 0}$ & $\mathbf{5 0}$ & 100 \\
\hline Machine rental & 90 & 110 & $\mathbf{2 0 0}$ \\
\hline Raw Material Storage (Rental Place) & 90 & 90 & 175 \\
\hline Laboratory Preparation & 120 & 125 & 125 \\
\hline Fruit Extract (Mix) & $\mathbf{n} / \mathbf{a}$ & $\mathbf{2 5}$ & \\
\hline
\end{tabular}

Source : Writer Team 2021

Table 3.3. Maklon Rental Details

\begin{tabular}{|c|c|c|c|}
\hline \multirow{2}{*}{ Asumsi HPP/Unit (Rp) } & \multicolumn{2}{|c|}{ Kemasan Tetrapack $250 \mathrm{ml}$} & \multirow{2}{*}{$\begin{array}{c}\text { Kemasan Family Pack } 1 \\
\text { L }\end{array}$} \\
\hline & Original & Mix & \\
\hline Harga Bahan Baku/Product & 750 & 1.000 & 1500 \\
\hline Kemasan pcs & 980 & 980 & 4.000 \\
\hline Sewa Makian & 1.000 & 1300 & 1500 \\
\hline Distribusi & 500 & 500 & 500 \\
\hline Asımsi Kenaikan HPP Tahin is 3,5\% & & & \\
\hline HPP/Unit (Rp) & 3.230 & 3.780 & 7.500 \\
\hline
\end{tabular}

Table 3.4 HPP Assumption

\begin{tabular}{|l|c|}
\hline \multicolumn{1}{|c|}{ Biaya Pra Operasional (Rp) } & Total \\
\hline & \\
\hline Permit cost & 20.000 .000 \\
\hline Office Renovation Cost & 50.000 .000 \\
\hline Preoperative Research Cost & $30.000-000$ \\
\hline \multicolumn{2}{|c|}{} \\
\hline Total & $\mathbf{1 0 0 - 0 0 0 . 0 0 0}$ \\
\hline \multicolumn{2}{|c|}{ Source : Writer Team 2021 }
\end{tabular}

\section{CONCLUSION}

Operational planning can produce Business/Business Establishment Stages, Operational Goals and Targets, Operational Design, Operational Delivery, and Projection of Operational Costs.

\section{Acknowledgement: None}

\section{Conflict of Interest: None}

Source of Funding: None

\section{REFERENCES}

1. S. Supriyanto, R. Indradewa, and T. Y. Rahmat Syah (2021), "Marketing Plan for Business Startups 'Jamu Partnership' in Indonesia," International Journal of Research and Review, vol. 8, no. 7, pp. 277-283.

2. Taryana, T. Yanuar Rahmat Syah, D. Fajarwati, and R. Indradewa (2021), "Implementation of Operational Strategy Planning in Area Corner Business" Journal of Multidisciplinary Academic, vol. 5, no. 6, pp. 118-123.

3. Prabangkara, T. Syah, and R. Indradewa, "Implementation of Operational Strategy Business In PT Maritim Industri Indonesia (MARINA) (2021). American International Journal of Business Management vol. 4, no. 06, pp. 178-183.

4. R. Ramadhan, T. Y. R. Syah, R. Indradewa, and D. Fajarwati (2020), "Determination of Factory Location PT . 
Saputra Tri Wardana et.al. Production and supply chain operation planning "minuman nanas" innovation of subang honey pineapple beverage.

Kelola Lingkungan Kita Using Factor Rating," Journal of Multidisciplinary Academic, vol. 04, no. 32, pp. 435-438.

5. Hardono, T. Yanuar, R. Syah, R. Indradewa, and A. Krisnanto (2021), "Operational System Exclusive Funeral Muslim in Indonesia 'Darul Muqamah Memorial Park," International Journal of Research and Review, vol. 8, no 8., pp. 679-686.
How to cite this article: Wardana ST, Indradewa R, Syah TYR et.al. Production and supply chain operation planning "minuman nanas" innovation of subang honey pineapple beverage. International Journal of Research and Review. 2021; 8(10): 345-354. DOI: https://doi.org/10. 52403/ijrr.20211047

$* * * * * *$ 